Original Article

\title{
EVALUATION OF HEAMAGGLUTINATION AND ANTI-CANCER POTENTIAL FROM INDIAN DIETARY PLANTS
}

\author{
MADHU C. S. ${ }^{1}$, SHARADA A. C. ${ }^{*}$ \\ ${ }^{1 *}$ Department of Biochemistry, Yuvaraja's College, University of Mysore, Mysuru, Karnataka, India 570005 \\ Email: sharadaac@gmail.com
}

Received: 04 May 2018 Revised and Accepted: 15 Jun 2018

\begin{abstract}
Objective: To evaluate the agglutination and anti-cancer activity of different dietary plants, commonly used in Indian dietary system for its therapeutic applications.

Methods: Sap/phloem exudates from different dietary plants were collected in phosphate buffer saline (PBS) was evaluated for lectin activity by using haemagglutination method in serial dilution manner. Anticancer activity of the different samples was evaluated against Ehrlich ascites carcinoma (EAC) cells by using trypan blue exclusion method.

Results: Samples belongs to Cucurbitaceae family showed promising lectin activity among test samples. Praecitrullus fistulosus and Cucumis prophetarum give $256 \mathrm{HU} / \mathrm{mg}$ whereas Cucumis dipsauses gives $128 \mathrm{HU} / \mathrm{mg}$ activity, whereas Abelmoschus esculentus (16HU) which gives low lectin activity. Praecitrullus fistulosus shows anticancer activity $67.38 \%$ inhibition at $200 \mu \mathrm{g}$ concentration followed by Cucumis prophetum of $56.36 \%$ at $200 \mu \mathrm{g}$ concentration against Ehrlich ascites carcinoma (EAC) cells.

Conclusion: The present study demonstrated that dietary lectin having a potential role in the biological field. High lectin activity demonstrates the anticancer effect in Ehrlich ascites carcinoma (EAC) model system, in vitro. Further study needs to isolate and evaluate biologically active lectin molecule in order to demonstrate the anticancer effect.
\end{abstract}

Keywords: Lectin, Dietary source, Agglutination, etc

(C) 2018 The Authors. Published by Innovare Academic Sciences Pvt Ltd. This is an open access article under the CC BY license (http://creativecommons.org/licenses/by/4.0/) DOI: http://dx.doi.org/10.22159/ijpps.2018v10i7.27110

\section{INTRODUCTION}

Lectins from plants are considered to be one of the major sources lectins which localized in various parts of plants [1]. However, numerous plant-based lectins have been well studied, but their physiological role of these lectins is poorly understood and it is argued that lectins which exhibit biological role need careful study in order to execute its molecular mechanism in the physiological conditions. Lectins found in dietary sources have thought to important part of the human diet. Dietary lectin represents an unavoidable constituent of our diet. These dietary lectins can cause harmful and beneficiary effects in human beings [2]. These lectins performed a wide variety of physiological functions including agglutination, immunomodulation, anti-inflammatory, anti-cancer and so on [3]. Intake of raw or cooked plant material containing lectins can travel through digestive tract from mouth to colon with a substantial part of the molecule remaining in the intact form [4]. These lectins exhibit resistance to the digestive process [5] and it seems to be biologically active throughout the alimentary canal and they perform any activities therein could be modified by inhibitory sugars in the diet [6]. Immunoglobulin-A (IgA) present in the human saliva may also neutralize its effect [7-8]. Although isolated and wellcharacterized lectins from edible sources, their toxicity upon treatment and their nutritional significance remain unknown. However, intake of purified lectins from the dietary sources and their possible physiological effects still remains unclear.

Cancer is a second leading disease which causes death every year and millions of people are diagnosed with the disease around the globe [9]. Due to adverse effects and complications, currently available chemotherapeutic agents have limitations in treatment. To overcome this problem, phytoconstituents from the plants exhibiting anti-cancer property are emerging as a tool in the prevention of tumor development [10]. Over more than $30 \%$ of cancer death was directly associated with the dietary food habits. This is due to the changes in dietary and adaptation of sedentary lifestyle and the burden of this disease are gradually increasing every day [11]. Various research groups were involved and put their effort in order to develop a new therapeutics against cancer by targeting multiple targets in a cellular system. Various experimental studies have demonstrated the cancer preventive effects of different lectins derived from these sources, which attains the greatest prospects in targeting cancer cells. Lectins are considered as one of the promising tools in order to treat and diagnose cancer. Lectins exhibit an anti-cancer property in various cancer cells by activating death pathway such as apoptosis and autophagy [12]. Earlier studies show that pea lectin induces apoptosis in Ehrlich ascites carcinoma (EAC) cells by arresting cell cycle at the G2/M phase and activate apoptosis pathway, in vivo [13]. In continuation of our research in identifying and developing anticancer molecules from medicinal plants, herein we screened the dietary plants for lectin and anticancer activity [14].

In this report, we screened the dietary plant's exudates in order to determine the presence of lectin as well as the anti-cancer potential to carry out the further work in future for identifying novel and potent molecule to combat against cancer.

\section{MATERIALS AND METHODS}

\section{Chemicals and reagents}

Potassium dihydrogen phosphate $\left(\mathrm{KH}_{2} \mathrm{PO}_{4}\right)$, Potassium manohydrogen phosphate $\left(\mathrm{K}_{2} \mathrm{HPO}_{4}\right)$, Sodium chloride $(\mathrm{NaCl})$, Copper sulphate (CuSO4) procured from SRL (Sisco research laboratories). FC reagent procured from Fischer scientific. Trypan Blue was procured from Sigma-Aldrich.

\section{Collection of plant materials}

Samples were collected from local area farmers, Mysore and authenticated by Dr. Sharvani K. A, Assistant professor, Department of Botany, Yuvraj's College, University of Mysore, Mysuru. The Herbarium (Accession number: YCM(UOM)0266) was prepared and deposited at Department of Botany, Yuvraj's College, University of Mysore, Mysuru, Mysore. 


\section{Preparation of extract}

The sap/phloem exudates from plants by incision with a sharp needle and oozing exudates were collected in a sterile tube containing cold 10 mmol phosphate buffer saline (PBS) and immediately transferred to a freezer at- $20^{\circ} \mathrm{C}$. Later the samples were removed from the freezer and centrifuged at 12,000 rpm for $15 \mathrm{~min}$. clear supernatant was transferred to a fresh tube and repeat the same procedure until getting a clear solution. The sample free from the debris was subjected to lyophilization, used for the further assay. The samples were named as follows, Cucumis dipsauses (S1-), Lagenaria siceraria (S2), Brassica oleracea gongylodes (S3), Abelmoschus esculentus (S4), Cucumis prophetarum (S5), Praecitrullus fistulosus (S6), Averrhoa carambola (S7) and Actinidia deliciosa (S8).

\section{Estimation of protein concentration by Lowry's method}

Protein concentration was determined as described earlier [15]. Briefly, $0.5 \mathrm{ml}$ of phloem exudates were incubated with the Lowry reagent for 10 min at $37^{\circ} \mathrm{C} .0 .5 \mathrm{ml}$ of FC (Folin-Ciocalteu) reagent (1:1) was added to reaction mixture and incubates the samples for $30 \mathrm{~min}$ at room temperature, and absorbance was read spectrophotometrically.

\section{Preparation of $2 \%$ red blood cells (RBC's) cells}

The blood was drawn from a healthy volunteer in a fresh tube containing Alsever's solution. Immediately mixture was centrifuged at $2000 \mathrm{rpm}$ for $10 \mathrm{~min}$ and transferred the pellet into the fresh tube containing hypo saline solution. Centrifuge the mixture for $10 \mathrm{~min}$ at $2000 \mathrm{rpm}$ and repeat the above step until getting the clear supernatant. The obtained packed RBC's cells were used for preparing $2 \% \mathrm{RBC}$ in $\mathrm{PBS}$ solution.

\section{Haemagglutination activity}

Agglutination assay was performed by using 96 well plates according to the method described earlier [16]. Briefly, samples (1 $\mathrm{mg} / \mathrm{ml}$ ) were two-fold serially diluted by using PBS in 96 well plates and $2 \%$ of RBC's were added to each well and incubate the plate at $37^{\circ} \mathrm{C}$ for $60 \mathrm{~min}$ and photographed. The haemagglutination activity was measured/expressed in terms of titer. Haemagglutination titer is defined as the minimum amount of protein required to form agglutination id referred as 1 titer value.
Evaluation of different dietary lectins samples for anticancer activity

\section{Ethical statement}

Mice were maintained as per the principles and guidelines of the Animal Ethical Committee for animal care, University of Mysore in accordance with Indian National Law on animal care and use. The experimental design and study were approved by Institutional Animal Ethics Committee (IAEC) (Ref No: UOM/IAEC/10/2017), University of Mysore, Mysore, Karnataka, India.

\section{Preparation of ehrlich ascites carcinoma (EAC) cells}

EAC cells resemble human tumors, which are originally hyperdiploid, rapid proliferative, high transplantable capacity, short life-span and 100\% malignancy. Ehrlich Ascites Carcinoma (EAC) cells $\left(5 \times 10^{6} \mathrm{cells} / \mathrm{mice}\right)$ were injected into the intraperitoneal cavity of the mice. The growth of tumor was monitored every day and recorded until the end of the experiment. Ehrlich Ascites Carcinoma (EAC) cells begin their exponential growth from the seventh day after the tumor cell injection and the animal succumbed to the ascites tumor burden on day 16-20 after injection.

The cells were washed with RBC's lysis buffer to remove RBC's contaminant and followed by saline until getting clear supernatant. The obtained cells were suspended in a culture flask containing RPMI 1640 media.

\section{Tryphan blue exclusion method}

Cytotoxic effect of lectin was determined as described earlier [17]. Briefly, a fixed number of Ehrlich ascites carcinoma (EAC) cells was seeded $\left(0.5 \times 10^{6}\right.$ cells $)$ in each 6-well plates and exposed the cells to different lectin samples $(100 \mu \mathrm{g}$ and $200 \mu \mathrm{g})$. Cytotoxic effect of different lectin samples was evaluated after $24 \mathrm{~h}$ by trypan blue exclusion assay and plotted as described earlier [18].

\section{Statistical analysis}

The experiments were carried out in triplicates $(n=3)$ and analyzed by one-way ANOVA (GraphPad Prism version 5.1). Values were expressed as mean $\pm \mathrm{SD}$.

Table 1: Screening of dietary lectins for agglutination activity $(n=3)$

\begin{tabular}{llll}
\hline S. No. & Plant species & Family & Titer value (HU/mg) \\
\hline S1 & Cucumis dipsauses & Cucurbitaceae & 128 \\
S2 & Lagenaria siceraria & Cucurbitaceae & 128 \\
S3 & Abelmoschus esculentus & Malvaceae & 16 \\
S4 & Brassica oleracea gongylodes & Brassicaceae & 32 \\
S5 & Actinidia deliciosa & Actinidiaceae & 64 \\
S6 & Praecitrullus fistulosa & Cucurbitaceae & 256 \\
S7 & Cucumis prophetarum & Cucurbitaceae & 256 \\
S8 & Averrhoa carambola & Oxalidaceae & 64 \\
\hline
\end{tabular}

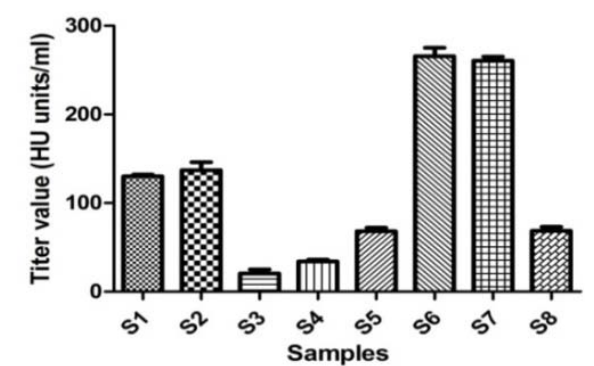

Fig. 1: Screening of dietary plants for lectin activity: A) Two-fold serial dilution of different lectin sample $(1 \mathrm{mg})$ was incubated with $2 \%$ trypsinized rabbit RBC's cells and incubated for $1 \mathrm{Hr}$ at $37^{\circ} \mathrm{C}$. visible agglutination was recorded. $10 \mathrm{mmol}$ phosphate buffer saline (PBS) was used as a negative control. Titer values were recorded as mean $\pm \mathrm{SD}$. The experiments were repeated thrice for each sample $(n=3)$

\section{RESULTS}

Eight samples were used to screen for the presence of lectin activity in their phloem exudates using haemagglutination assay by using rabbit erythrocytes. The phloem exudates Praecitrullus fistulosus and Cucumis prophetarum exhibit high lectin activity of $256 \mathrm{HU} / \mathrm{mg}$ at $200 \mu \mathrm{g}$ followed by Cucumis dipsauses which give $128 \mathrm{HU} / \mathrm{mg}$ titer (table 1, fig. 1). Dietary lectins from plant origins gain an attention due to its promising anti-cancer tools in the field of cancer biology. Cytotoxic effect of different lectin sources was determined by using Ehrlich ascites carcinoma (EAC) cells in vitro. Fixed number of Ehrlich ascites carcinoma (EAC) cells were exposed to different lectin samples for $24 \mathrm{hr}$ and cytotoxic potential was determined by trypan blue exclusion method. Results exhibit the highest cytotoxic potential observes Praecitrullus fistulosus and Cucumis dipsauses, up to $67.38 \%$ and $56.36 \%$ at $200 \mu$ g followed by other lectins sample as shown in fig. 2. Other lectin samples show moderate anti-cancer activity and their inhibition was found to be Cucumis dipsauses (45.08\%), Lagenaria siceraria (53.59\%), Abelmoschus esculentus 
(20.33\%), Brassica oleracea gongylodes (44.99), Averrhoa carambola (43.78\%) and Actinidia deliciosa (34.76\%) at $200 \mu \mathrm{g}$ concentration.

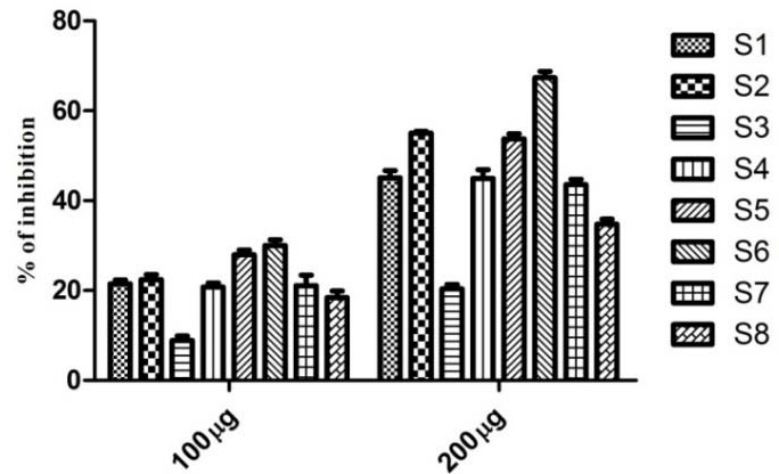

Fig. 2: Screening of dietary plants for anti-cancer activity: fixed numbers of cells $\left(0.2 \times 10^{5}\right.$ cells $)$ were exposed to different lectin sample at $100 \mu \mathrm{g}$ and $200 \mu \mathrm{g}$ for $24 \mathrm{hr}$ and cytotoxicity was assessed by trypan blue exclusion method by using hemocytometer. 10 mmol phosphate buffer saline (PBS) was used as negative control.

The cytotoxic potential of each lectin sample was expressed as mean \pm SD $(n=3)$

\section{DISCUSSION}

For many years, it was believed that lectins are a toxic substance which may harmful to physiological activity. Later in 1970's work led by shows the potential application of lectins in the field of biology [19-21]. According to Dr. Peter J. D'Adamo "eat right for your blood type", which explains the significant effect of lectin in the diet. Lectins present in the sap/phloem exudates which plays an important role in plant defence system as well [22]. In the present investigation, we screened the dietary plant's phloem exudates for lectin activity by using rabbit erythrocytes. The phloem exudates from Praecitrullus fistulosus, Cucumis prophetarum, and Cucumis dipsauses exhibit high lectin activity. Interestingly all the above-said species belongs to Cucurbitaceae family. Earlier reports showed that presence of lectin in the phloem exudates Cucurbitaceae species supports our findings [23]. The lectin present in the phloem exudates named as phloem protein-2 (PP-2) which acts as a defence mechanism in Cucurbita species. Majority of the phloem exudates lectins were chitin specific, especially chitooligosaccharides specific protein which is reported earlier [24]. But studies on their biological activity in disease care and management is limited. It is urged to explore the biological activity in developing a new therapeutics to combat the various diseases. Among these plants sap of okra plant showed negligible lectin activity, due to the presence of low amount of protein. Further presence of lectin in the seeds of okra was reported [25].

Dietary lectins from plant origin gain an attention due to its promising anti-cancer tools in the field of cancer biology. Lectins were used as diagnosing marker and killing agents in cancer treatment [26]. Cytotoxic effect of different lectin samples was determined by using Ehrlich ascites carcinoma (EAC) cells in vitro by trypan blue exclusion method. Again samples from Praecitrullus fistulosus possess promising anticancer activity followed Cucumis prophetarum. Interestingly, low lectin activity samples also exhibit cytotoxic potential against cancer cells. This may due to the presence of soluble bioactive peptides/proteins and other small molecules which may responsible for the cytotoxic potential of cancer cells [27]. Lectins present in the plant sources acts on cancer cell by recognizing extensive glycosylation level on the cell surface compared to normal cells [28]. This may be the one of the possible mechanism in order to control the cell proliferation and thereby it controls the cancer progression. Some lectins act as immunomodulators and modulate the immune cells and thereby affects the cancer cell proliferation [29]. In the other hand, lectin recognized and binds to cancer cells surface and may internalize through endocytosis or phagocytosis mechanism. The internalized lectin activates the cell death pathways such as apoptosis or autophagy [30]. This induces the cancer cells leads to death and thereby control and kills cancer [13]. Altogether, our preliminary work provides a compressive perspective for elucidating the molecular mechanism of dietary plant lectins that may help in targeting glycosylation pattern and apoptotic pathways for cancer prognosis and therapeutics.

\section{CONCLUSION}

The observation in the study reveals the pharmacological significance of the dietary lectins. Lectins from various dietary sources induce agglutination in rabbit erythrocytes by binding to cell surface glycans. Praecitrullus fistulosus and Cucumis prophetarum have significant lectin activity and comparable with the other lectin sources. Interestingly, Praecitrullus fistulosus and Cucumis prophetarum posses promising anticancer activity against Ehrlich ascites carcinoma (EAC) cells, in vitro. These results confirm the lectins present in the dietary sources was responsible for the anticancer activity against Ehrlich ascites carcinoma (EAC) cells. The lectin-cell interactions and inhibitory activity of cancer cells developing lectin-based cell-based biological response tools in health and disease.

\section{ABBREVIATION}

PBS: phosphate buffer saline, HU: haemagglutination unit, EAC: ehrlich ascites carcinoma, PP-2: phloem protein-2, RBC's: red Blood cells, FC: folin-ciocalteu

\section{ACKNOWLEDGEMENT}

MCS kindly acknowledges the Teresian Research Foundation and Dr. H. N Yajurvedi, DOS in Zoology, University of Mysore, Mysuru-11, for providing Rabbit blood for the experiments.

\section{Funding sources}

This research did not receive any specific grant from funding agencies in the public, commercial, or not-for-profit sectors.

\section{AUTHORS CONTRIBUTIONS}

Madhu CS designed and perform the work and Dr. Sharada A. C helps to prepare the manuscript and data interpretation.

\section{CONFLICT OF INTERESTS}

The Authors declare that there is no conflict of interest

\section{REFERENCES}

1. Manen JF, Pusztai A. Immunohistochemical localization of lectin in cells of Phaseolus vulgaris L. seeds. Planta 1982;155:328-34.

2. Rabia H, Akbar M. Dietary lectins as disease-causing toxicants. PJN 2009;8:293-303.

3. Dan X, Liu W, Nq TB. Development and applications of lectins as biological tools in biomedical research. Med Res Rev 2016;36:221-47.

4. Kilpatrick DC, Pusztai A, Grant G, Graham C, Ewen SWB. Tomato lectin resists digestion in the mammalian alimentary canal and binds to intestinal villi without deleterious effects. FEBS Lett 1985;185:299-305.

5. Pusztai A, Greer F, Grant G. Specific uptake of dietary lectins into the systematic circulation of rats. Biochem Soc Trans 1989;17:481-2.

6. Wang Q, Yu LG, Campbell BJ, Milton JD, Rhodes JM. Identification of intact peanut lectin in peripheral venous blood. Lancet 1998;352:1831-2.

7. Gibbson RJ, Dankers I. Association of food lectins with human oral epithelial cells in vivo. Arch Oral Biol 1983;28:561-6.

8. Gibbson RJ, Dankers I. Immunosorbent assay of interactions between human parotid immunoglobulin and dietary lectins. Arch Oral Biol 1986;31:477-81.

9. Jemal A, Bray F, Center MM, Ferlay J, Ward E, Forman D. Global cancer statistics. CA: Clin J Clin 2011;61:69-90.

10. Preetha A, BK Ajaikumar, S Chitra, BH Kuzhuvelil, TT Sheeja, SL Oiki, et al. Bharat, cancer is a preventable disease that requires major lifestyle changes. J Pharm Res 2008;25:2097-116. 
11. Duthie SJ, Jenkinson AM, Crozier A, Mullen W, Pirie L, Kyle J, et al. The effects of cranberry juice consumption on antioxidant status and biomarkers relating to heart disease and cancer in healthy human volunteers. Eur J Nutr 2006;45:113-22.

12. Liu B, Bian HJ, Bao JK. Plant lectins: potential antineoplastic drugs from bench to clinic. Cancer Lett 2010;287:1-12.

13. Liu Z, Luo Y, Zhou TT, Zhang WZ. Could plant lectins become promising anti-tumour drugs for causing autophagic cell death? Cell Prolif 2013;46:509-15.

14. Ramzi AG, Puneeth HR, Madhu CS, Sharada AC. In vitro anticancer and anti-lipoxygenase activities of chia seed oil and its blends with selected vegetable oils. Asian J Pharm Clin Res 2017;10:124-8.

15. Lowry $\mathrm{OH}$, Rosebrough NJ, Farr AL, Randall RJ. Protein measurement with the folin phenol reagent. J Biol Chem 1951:193:265-75.

16. Chan YS, Ng TB. A lectin with highly potent inhibitory activity toward breast cancer cells from edible tubers of Dioscorea opposite cv. Nagaimo. PLOS One 2013;8:e54212.

17. Srivastava M, Hegde M, Chiruvella KK, Koroth J, Bhattacharya S, Choudhary B, et al. Sapodilla plum (Achras sapota) induces apoptosis in cancer cell lines and inhibits tumor progression in mice. Sci Rep 2014:4:6147.

18. Shital A, Santhosh B, Rabindra N. In vitro cytotoxic activity of novel oleanane-type of triterpenoids saponin from the stem bark of Manikukara zapota linn. Asian I Pharm Clin Res 2012;5:183-8.

19. Kocourek J, Liener IE, Sharon N, Goldstein IJ. editors. Historical background. In: The lectins: Properties, Functions, and Applications in Biology and Medicine. Academic Press: London; 1986.

20. Timoshenko AV, Gabius HJ. Efficient induction of superoxide release from human neutrophils by the galactoside-specific lectin from Viscum album. Biol Chem 1993;374:237-43.
21. Lis H, Sharon N. Lectins as molecules and tools. Annu Rev Biochem 1986;55:35-67.

22. Peumans WJ, Van Damme EJ. The role of lectins in plant defence. Histochem J 1995;27:253-71.

23. Sultan NAM, Kavitha M, Swamy MJ. Purification and physicochemical characterization of two galactose-specific isolectins from the seeds of Trichosanthes cordata. IUBMB Life 2009;61:457-69.

24. Van Damme EJM, Rouge P, Peumans WJ. Plant lectins. Comphrensive Glycoscience 2007;3:563-99.

25. Monte LG, Santi Gadelha T, Reis LB, Braganhol RF, Dellagostin OA, Lacerda RR, et al. Lectin of Abelmoschus esculentus (okra) promotes selective antitumor effects in human breast cancer cells. Biotechnol Lett 2014;36:461-9.

26. Mody R, Anataram J, Chaney W. Use of lectins as diagnostic and therapeutic tools for cancer. J Pharmacol Toxicol Methods 1995;33:1-10.

27. Gonzalez Montoya M, Cano Sampedro E, Mora Escobedo R. Bioactive peptides from legumes as anticancer therapeutic agents. Int J Cancer Clin Res 2017;4:81.

28. Stowell SR, Ju T, Cummings RD. Protein glycosylation in cancer. Annu Rev Pathol 2015;10:473-510.

29. Pramod SN, Vigneshwaran V, Venkatesh YP. Immunomodulatory effects of haemagglutinating lectins from potato (Solanum tuberosum) and garlic (Allium sativum) on human and murine lymphocytes. Int J Pharm Pharm Sci 2015;7:147-53.

30. Liu B, Cheng Y, He-jiao Bian, Bao Jk. Molecular mechanisms of Polygonatum cyrtonema lectin-induced apoptosis and autophagy in cancer cells. Autophagy 2009;5:253-5. 